\title{
MAGE-1 Antigen
}

National Cancer Institute

\section{Source}

National Cancer Institute. MAGE-1 Antigen. NCI Thesaurus. Code C1387.

A cancer specific antigen expressed by the melanoma antigen gene. 